\section{高齢者のライフスタイルと 快適覚醒·快適睡眠}

堀 忠雄（広島大学総合科学部）

\section{1.はじめに}

平成 14 年度の総務省統計では 65 歳以上の高齢者人口 が 2,363 万人で、高齢化率は 18.5 に達し、そのうち 75 歳以上の後期高齢者が 1,004 万人を占めている。加齢と ともに睡眠効率が低下し、睡眠問題が増加することは良 く知られたことであるが、高齢者の睡眠と覚醒の最適管 理計画は十分な整備がなされているとは言いがたい状況 であり、科学的デ一夕の蓄積と提言が緊急課題となって いる。このシンポジウムでは「高齢者のライフスタイル と脳・心身の健康」という切り口から、高齢者の睡眠と 覚醒の実態を把握し、さらに質の良い日中覚醒を維持す るための生活管理技術の開発状况を、具体例に基づいて 検討することにした。この報告では高龄者の睡眠実態を 概観することにする。

\section{2. 高齢者は短時間睡眠か}

年齢別に就床・起床時刻と睡眠時間を比較すると、前 学童期の 6 歳未満から 40 歳代までは睡眠時間は短縮す るが、 50 代から徐々に延長し 80 歳以上の超高齢者では 8 時間 30 分以上になる。「高齢者の睡眠は短時間である」 という思い込みは誤りであり、実際には服りが浅くなつ た分を睡眠時間の延長によって補償していることがわか る。また起床時刻は社会生活に規定されるため、年齢差 は僅かであるが、就床時刻の前進で睡眠時間の延長を実 現しているのが特徵である（白川ら 1996）。

早寝早起きは健康な生活習慣と考えれているが、それ では高齢者の早寝早起きは生体リズムの管理から見て、 適正なことといえるのであろうか。生体リズムの位相前 進は位相後退よりも難しいことが指摘されているが、な ぜ高齢者では就床時刻を前進させて睡眠時間の確保が可 能になっているのであろうか。

\section{3．高齢者の生体リズムと早朝覚醒}

超短縮睡眠-覚醒スケジュールによる眠気曲線の測定 結果（Haimov \& Lavie 1997）では、若年者（19-26 歳） と高齢者(65-78 歳の睡眠傾向曲線を比較すると、睡眠禁 止帯がおよそ 12 時間ずれており、若年者では 19:00-21:00 に認められるが、高齢者では 7:00-9:00 に認 められる。高齢者の早朝覚醒は社会的要因ではなく、生
体リズムの加齢現象としておこる睡眠禁止帯の極端な前 進が原因であることが分かる。一方、睡眠ゲートの開始 は22:00 で群間に差は認められていない。ところが高齢 者では 19:00-21:00 の睡眠禁止帯が前進しているため、 この時間帯で入眠が可能となっている。早朝覚醒と睡眠 相の前進は加齢による生体リズムの歪みを反映したもの で、適応的な現象ではないことを示している。

また、睡眠傾向（睡眠圧）のピーク時刻はおよそ 5:00 で変わらないが、その強さには差が認められ高齢者のほ うが低い。高齢者の睡眠傾向は 5:00-7:00 に急激な低下 を示していることから、早朝覚醒はさらに 5:00ごろまで 前進する可能性を示している。

日中の覚醒水準には群間差が見られていない。これま では、高齢者は睡眠不足になるため日中の覚醒水準が低 くなりやすく、このことが高齢者の習慣的昼寝の原因と 説明されてきた。睡眠傾向曲線のデー夕は、快適な日中 の覚醒水準を維持するために昼寝をしており、睡眠不足 を補償するというよりも、意欲的なライフスタイルの行 動項目として積極的に取り込んでいる可能性が指摘され ている。夜眠れないので昼間に寝ているのでなく、より 良く生きるために昼寝をしているという、これまでとは 違つた観点が指摘されている。

生体リズムの加齢現象としては、概日リズムの内部同 調機能の低下が指摘されている（白川ら 1996）。若年 者では体温リズムと睡眠覚醒リズム、あるいは活動休止 リズムの間に強固なリズム同調が維持されているが、高 齢者では加齢により内部同調機能が低下し、2つのリズ ムが内部脱同調を示すようになる。高龄者では体温リズ ムと睡眠覚醒りズムの周期に乘離が起こりやすく、環境 サイクルに対しても位相前進を示すなど、同調機能が全 般的に低下することが指摘されている。睡眠覚醒リズム を再同調させる試みとして、日光浴、生活の規則化、日 中の活動性確保などの試みが成果をあげていることは、 この問題の解決に時間行動学的な取り組みが重要である ことを示唆している。

\section{4. 加齢により睡眠の性差が顕著になる}

睡眠段階の出現率（\%）を年代ごとに比較した報告で は、加齢による段階 3.4 (徐波睡眠) の減少と中途覚醒 の増加が顕著である( Williams et al 1974)。特に男性に この傾向は顕著に現れ、65 歳以上の高齢者では $5 \%$ 以下 にまで減少する。一方女性では 70 歳代の後期高齢者で も $10 \%$ 前後の出現率を維持しており、中途覚醒や段階 1 
などの浅眠の増加も抑えられている。睡眠時間も 40 歳 代以降で性差が顕著になり、男性の方が短い。中途覚醒 の回数も男性の方が多く、特に 20 歳代と 60 歳代で有意 な差を示す。睡眠効率にはかなりの個人差があるため、 目だった性差は報告されていないが、男女とも 50 歳代 から低下し始め、70 歳代でさらに大きな低下を示してい る。

睡眠に対する主観判断では、睡眠満足度に明瞭な性差 が認められている(井上 1988)。男性は 10 歳代後半か ら 70 歳代までほぼ直線的に低下を示すが、女性では 50 歳代に入ると突然のように満足度が急低下する。すでに 睡眠変数で見たように、徐波睡眠の減少と中途覚醒の増 加、睡眠時間の短縮は男性の方に顕著に現れていた。と ころが主観評価では逆転して、女性に強い不満があり生 理・行動指標と主観指標とに乘離が認められる。

スイスの報告(井上 1988)では睡眠薬を使用する人の 割合は 50 歳代以降で急激に増加し、特に 70 歳代の女性

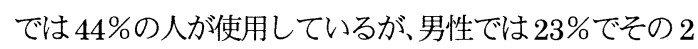
分の 1 程度である。なぜ、女性は 50 歳代から急激に睡 眠不満が高まるのか、その理由は分かっていない。更年 期と時期が重なっていることから、ホルモンとの関係を 指摘する報告もあり、ホルモン補充療法により睡眠が改 善されるという報告もあるが、ライフサイクルの変化に 伴なう心因性の問題を指摘する報告もあり、結論は出て いない。

\section{5. 日本における不眠症の実態}

1997 年の国立保健医療科学院（旧国立公衆衛生院） が中心となって実施された「睡眠と健康に関する全国調 査」(Doi et al 2000)では、20 歳以上の日本人男性 920 人、女性 951 人、計 1,871 人を対象に不眠症の実態調査 を行っている。不眠症を過去 1 ケ月間、週 3 回以上の頻 度で (1) 30 分以内に眠ることが出来なかった（入眠困 難)、(2) 同じ頻度で夜間に中途覚醒したものと定義して その頻度 (有症率) を調べると、男性で $17.3 \%$ 、女性で $21.5 \%$ であった。年齢分布を比較すると、20 歳代と 70 歳代以上で女性の有症率が高くなるが統計的な有意差を 示すまでには至っていない。しかし、80歳代では女性が 40.3\%、男性で $30.5 \%$ が不眠症であることは、睡眠管理 の重大性を示している。人口統計では年代の区切りを 75 歳以上（後期高齢者）としているため、正確な人数把握 は出来ないが平成 14 年度で 75 歳以上の後期高齢者は男 性が 364 万人、女性が 641 万人であるので、上記の比率
で試算すると男性が 109 万人、女性が 256 万人、合計す ると 365 万人が不眠症で苦しんでいることになる。

次に過去 1 ケ月間の睡眠について眠りの質が「かなり 悪い」「非常に悪い」という自己評価を「主観的な質の 悪さ」と定義してその有症率を調べると、全体の平均は 男性 $17.8 \%$ 、女性 $20.2 \%$ であった。睡眠変数で追跡する と、男女とも睡眠の質は年齢を追うごとに低下している。 ここから推測されることは、不眠症の有症率と同様に「睡 眠の質の悪さ」も年齢を追うごとに増加するであろうと いうことである。ところが男性ではその逆で、年齢が若 いほど「睡眠の質が悪い」と思う人の割合が大きく、高 齢期でその割合は最小となっている。他方、女性は若い 人と 70 歳以上の人で割合が高くなり、70歳代以降では 男性に比べ「睡眠の質が悪い」と思う人の割合がおよそ 2 倍に達し、統計的にも有意に高い結果となっている。

過去 1 ケ月間で週 3 回以上の頻度で睡眠薬を服用して いる人を「眠剤の常用者」之定義して調べると、全体の 平均は男性で $3.5 \%$ 、女性で $5.4 \%$ であった。年齢が高く なるほど「眠剤を常用」する人の割合が増加する。年齢 別に性差を比較すると、50歳代と 80 歳代で有意差が認 められている。5 歳代では男性が 1.4\%であるのに対し、 女性は $8.8 \%$ でおよそ 6 倍である。 80 歳代では男性 $10.2 \%$ 、女性 $21.8 \%$ で男女比は 2 倍である。わが国の実 態調査でも睡眠不満と眠剤を常用する人の割合は、高齢 女性のほうが高いという結果となっている。

\section{6. 快適覚醒と快適酫眠の確保に向けて}

生理指標や行動指標からは男性高齢者のほうが睡眠不 満が強く、睡眠薬の常用や日中の低覚醒（強い眠気や居 眠りの発生）の頻発が推測される。ところが、これらの 指標からは加龄効果が比較的緩和されていると考えられ る女性のほうが、睡眠不満が強く睡眠薬の常用など問題 が深刻化している。人口比から見ても高齢人口は女性が 大きな割合を占めており、社会問題としても不眠と睡眠 不満に見ら机る性差のメカ二ズムの解明とその解消に向 けた対応が求められている。

睡眠薬の持ち越し効果や睡眠不足による日中覚醒の低 下や動摇は高齢者の日中覚醒を劦かす要因であり、生 活の質（QOL）を確保するためにも、睡眠問題の適切な 治療と快適覚醒の指導が必要である。睡眠と覚醒の力動 関係の調整だけではなく、概日リズムの内部脱同調など の対策には、時間行動学的な理解と取り組みが期待され ている。 


\section{高齡者の覚醒時脳波と睡眠習慣について}

\author{
水上 喜美子 \\ (仁愛大学人間学部)
}

【はじめに】

近年, ヒトの寿命の延長は著しく, その結果, こ れまで以上に老年期が長くなってきている.一般に， この老年期は，個体の機能が次第に衰えていく老化 の時期とされてきた。ここで，老化とは，成熟した 後にひきつづいておこる生体の臟器や組織の形態的 変化, 機能低下と定義づけられている. しかし, こ のような身体的・生物学的変化とは異なり，心理的 機能や側面には成熟期以後も発達を続ける機能があ るといわれている.最近では，心理的な加㱓過程を 「生涯発達」という視点でとらえようとする立場が, 発達心理学の分野において新たに提唱され始めてき ている.すなわち, 老年期は, 従来のような老化と 一義的に定義できない側面もあるのである．また， Baltes(1987)は，そもそも発生学的に見れば，成長 と老化は表裏一体の現象であるとしている.

このような心理的機能や側面を司る最高の中枢は， 脳であり，この脳の機能を直接的・動的・客観的に とらえ，比較的簡便に非侵襲的に脳機能を測定する 方法として脳波があると考えられる。そこで，高歯 者の脳波を検討することで，高歯者の心理的機能・ 側面を推測できるのではないかと考えられる.

ここで，脳波の時間的変化は long term と short term とに分けて検討していく必要があると考えら れる. short term の変化としては，覚醒から睡眠 への変化などが考えられ， long term の変化として は発達や老化が考えられる.そこで，本研究では， 覚醒時脳波について覚醒・睡眠的側面と老化的側面 について検討していくこととする。

\section{【本研究の測定・調査概要】}

1. 対象者: 在宅で生活をする高㱓者 123 名(平均 年齢 : 76.16 歳), 男性 26 名, 女性 97 名を対象とし た.ここで，年齢範囲は 60 歳から 94 歳と，34 年 間という相違があるため，生理的にも心理的にも大 きな差違があることが考えられた．そこで，便宜的 に，2つのグループに分け，60～74 歳を前期高齢者 群, 75 94 歳を後期高歯者群とした. 前期高齢者群 は 49 名(69.8 歳)で, 後期高歯者群は 74 名(80.3 歳) であった.このうち，脳波記録への協力者は 89 名
であった。

2. 調查時期および調查場所 : 調査時期は， 2002 年 8 月上旬 9 月中旬で, 調查場所は $\mathrm{O}$ 市の老人福 祉センターであった。

3. 方法 3-1. 党醒時脳波: 脳波は, 国際 10-20 法に基づく 12 部位を活性電極とし, 右耳の耳桑を 基準電極導出法により導出した. 座位, 安静閉眼の 状態で記録をした。

3-2. 記録装置 : 脳波の記録には, 多用途テレメ 一タサイナアウト MT11(NEC 製)を用いた.信号は, 多用途生体情報解析プログラム (KISSEI COMTEC 社製にによりサンブリング頻度を $500 \mathrm{~Hz}$ として $\mathrm{A} / \mathrm{D}$ 変換し,ノート型パソコンのディスクに 収録した。

3-3. 結果の処理法 : 脳血管障害・脳腫瘍の既往 歷，痴呆症状が認められた事例，アーチファクトの 混入により 3 分間の記録が得られなかった事例は分 析対象から除外し，77 名を分析に用いた. 本研究で は, 8 部位 $\left(\mathrm{F}_{7}, \mathrm{~F}_{8}, \mathrm{C}_{3}, \mathrm{C}_{4}, \mathrm{~T}_{5}, \mathrm{~T}_{6}, \mathrm{O}_{1}, \mathrm{O}_{2}\right)$ につ いて, 周波数の分解能を $0.25 \mathrm{~Hz}, 512$ 点(約 4 秒)を 1 エポックとし，ハニング空による平滑化処理を行 った. 次に, FFT 解析を行いオートパワスペクトル を求め, 15 エポックのオートパワスペクトルから平 均パワスペクトルを算出した。さらに，算出された 平均スペクトルの中で最もパワ一值が高かった成分 (優勢成分)を求めた。

4. 手続き : 実験者が測定・調査の目的, 参加者の 申し出によっていつでも測定・調査を中止できるこ とを充分に説明したうえで，同意書に参加者のサイ ンを得てから測定・調査を開始した。

\section{【研究 I】}

1. 目的 まず， short term の側面として，覚醒・ 睡眠の変化に注目し，高齢者の睡眠習慣と高粭者の 覚醒時脳波，ここでは特に脳波の優勢周波数のピー ク周波数との関係について検討した．また，精神的 健康度 $(\mathrm{GHQ})$ を指標とし，心理的側面への影響につ いても調べることにした。

2. 調查内容 $a$ 睡眠調查 : 睡眠の健康と生活・睡 眠習慣に関する調査票(堀,1998)を参考に，10 項目 の睡眠に関する項目を作成した.「あなたの睡眠時間 は平均してどれぐらいですか」,「布団に入ると，す ぐに眠れますか」などの項目からなる. 
b 精神的健康度 : 日本版 GHQ 精神健康調査票(以下 GHQ)の短縮版の 12 項目を質問項目として用いた. この質問紙の下位尺度は，不安・抑うつと活動障害 の 2 尺度から構成されている.「いつもストレスを 感じたことがありましたか?」などの質問項目で， 「たびたびあった(1)一まったくなかった(4)」という 4 件法での回答を求めた. GHQ 得点の範囲は 12 点 から 48 点で, 精神健康状態が良好なほど得点が高 くなる.

3. 結果 3-1. 高怔命者の睡眠習慣 睡眠習慣と 年代(前期と後期), 性別について検討した.この結 果，年代では前期より後期高齢者群の方が眠りにつ く時間が早く $\left(\chi^{2}(1)=3.81, p<.05\right)$, 入眠に問題がな $<\left(\chi^{2}{ }_{(1)}=3.90, p<.05\right)$, 夜間のトイレの回数が多く $\left(\chi^{2}{ }_{(1)}=4.73, p<.05\right)$, 昼寝の習慣がある $\left(\chi^{2}(1)=\right.$ $6.24, p<.05)$ ということが認められた. この後期高齢 者群では, 布団に入るとすぐに眠れる(入眠の問題が ない)と答えた人の中で, 睡眠薬を服用していると回 答した人が $13.7 \%$ を服用する割合が増えていることは認められなかっ たが $\left(\chi^{2}{ }_{(1)}=1.91\right.$, n.s. $)$, この睡眠薬の服用者は, 前 期高齢者群では $4.0 \%$ で 後期高歯者群では $18.8 \%$ と増えていることが注目に值すると考えられる.

また，性別では，女性(47.8\%)よりも男性(75.0\%) において 7 時間以上の睡眠時間の人が多い $\left(\chi^{2_{(1)}}=\right.$ $4.61, p<.05)$ という結果も得られた.

$3-2$. 睡眠習慣と覚醒時脳波および精神的健康度 (GHQ)との関係 ここでは, 睡眠習慣と脳波の優勢 周波数のピーク周波数と精神的健康度との関係につ いて検討した.この結果, 睡眠習慣とピーク周波数 の間では差違を認めることはできなかった.

しかしながら，睡眠時間が十分だと回答した人 $\left(t_{(68)}=1.96, p<.05\right)$, 入眠に問題がないと回答した人 $(t(71)=2.25, p<.05)$, 熟睡していると感じていると回 答した人 $(t 65)=2.88, p<.01)$ ほど, 精神的健康度が良 好であることが認められた。

以上のことより, 睡眠習慣の相違は心理的側面で ある主観的健康感に影響していることが認められた が, 覚醒時維持機能に反映しているという結果は認 められなかった。

\section{【研究II】}

1. 目的 次に, long term の側面として, 加歯に
よる変化に注目し，高齢者の覚醒時脳波について検 討した.

これまでの研究より,加齢に伴う脳波変化として, (1)背景脳波の徐波化 ( $\alpha$ 波周波数の徐波化, 広汎化, $\theta$ 波増加), (2)反応性の変化(開眼による $\alpha$ 波の抑 制の低下など)，(3)則頭部領域の特殊波形の出現，(4) 主に入眠期に出現する特殊波形の増加などの特徴が ある(松浦,2003）とされている.そこで，加歯にと もない優勢成分の周波数が変化していくのかを検討 するために，周波数スペクトルに示された優勢周波 数と暦年齢・性別との関係について調べた。

2 . 結果 覚醒時脳波と暦年齢・性別との関係 加 齿令の影響を調べるために，暦年跲により，前期高齢 者群と後期高齢者群の 2 群に分類し, 各部位におけ る優勢成分のピーク周波数において相違が認められ るのかについて検討した.

この結果, どの部位においても差違は認められな かった $\left(\mathrm{eg} . \mathrm{O}_{1}: t_{(66)}=0.28\right.$, n.s. $)$. しかし,「個人差」 について検討した結果，どの部位においても，前期 に比べて後期高秢者群の方が個人差分散が大きいこ とが認められた (eg. $\left.\mathrm{O}_{1}: F_{(42,33)}=3.64, p<.01\right)$. また， 各部位の優勢成分のピーク周波数については, 男性 に比べ女性の方がピーク周波数は高い $\left(\mathrm{eg} . \mathrm{O}_{1}\right.$ : $\left.t_{(75)}=2.37, p<.05\right)$ という結果であった.

これらのことより, 歴年齢と優勢周波数は, 必ず しも比例関係ではないことが明らかになった.また， 優勢成分のピーク周波数のレンジが, 前期高齢者群 に比べ後期高齢者群において広くなっていることが 認められたことから, 加齢にともない脳波の変動が 多様化しているということが示唆された.

\section{【まとめ】}

覚醒時脳波について覚醒・睡眠の側面と老化の側 面から検討した結果, 覚醒時脳波は睡眠習慣の影響 を受けにくいこと，暦年齢よりも性別と関係する指 標であることが認められた。

加齢が進むにつれて, 覚醒時脳波のピーク周波数 にばらつきが目立つようになり， $\alpha$ 波の徐波化を加 跉の特徵とした場合に，徐波化が著しい高齢者とそ うでない高齢者とがいることが認められた。

これらのことより, 暦年齢のみを基準にして, 高 路者を区分することの妥当性について検討していく 必要があると考えられる. 


\section{施設高齢者の光環境整備と睡眠覚醒リズム}

○中野 紀夫 (松下電工 (株) 電器R\&Dセター)

\section{1. 背景}

ヒトの睡眠には加齢変化があり、若年群に比し高齢群で は深い睡眠の減少や中途覚醒の増加がしばしば観察され る。また不眠など睡眠障害の割合も増加する。高齢者にと つて良い睡眠を確保することは生活の質（Q0L）を維持す る上で高い関心事である。また痴呆を有する高齢者では昼 間の傾眠や夜間の不眠に加え、徘䧃や不穏などの異常行動 が現れる場合があり、介護の観点から生活リズムの安定化 が課題となっている。

本稿では、施設高齢者の睡眠覚醒リズム適正化を目指し た光環境整備の理論的背景と手法について述へ、導入効果 の事例を示す。

\section{2. 高齢者の睡眠覚醒リズムと光}

時間生物学の発展とともに、高齢者の睡眠障害には生体 リズム機能の低下が関係しているのではないかという考 えが広まってきだ!若年者に比べ高齢者では、睡眠機能 に関係する深部体温やメラトニンの日内変動振幅が低下 する傾向が見られるが、睡眠障害を持つ高齢群ではその傾 向が顕著であることが報告されている ${ }^{[2] 。 ~}$

生体リズムの機能低下を補う非薬物的手法として毎日 一定時刻に高照度光を浴びる光療法が提案さている。高照 度光は覚醒度を高め維持するとともに生体リズムの安定 化効果（位相の固定、振幅の増強）が期待できる。1990 年代より高齢者への適用が広がり、夜間睡眠の改善 ${ }^{[3-5]}$ 示す成果が報告されている。

また生活活動レベルが低下した施設高齢者は、低照度で 照度変化の少ない室内で生活の大半を過ごしがちである。 その結果、高照度光への暴露や社会的活動などの生体リズ ムの同調因子が不足し、睡眠障害を増悪させる要因となる。

\section{3. 光環境整備に用いられる照明器具}

睡眠覚醒リズムの改善を狙った光照射には、従来ボック 又型の高照度光照射装置（図1 (a)）が多く用いられてき た。医療用器具では、顔面から数十 $\mathrm{cm}$ 前方に設置し概小 2, 5001x 以上の照度が得られるよう設計されている。光の 生理的効果は、受光量（明るさ $\times$ 時間 $\times$ 光特性）の影響 が大きいと考えられており、顔面での照度に加え受光時間 や設置位置を考慮する必要がある。受光時間は実用的には
数十分から数時間までであるが、必ずしも光源を視野中心 に固定しなくてよい。まぶしさ感を減らすために、周囲の 照度をできるだけ高くするとともに、発光面の輝度むらが 小さい光照射装置を選ぶ。

より自然な形で受光量を高めるため、近年では室内空間 の広い範囲を対象にした光環境整備が実用化されつつあ る。図 1 (b) は、老人保健施設のデイルームにコ一ナ一型 の高光束照明設備を設置した例である。自動制御により午 前後半点灯させ、室内を高照度空間（通常 $3001 \mathrm{x} \rightarrow$ 設備点 灯時 2, 8001x）にする。入居者は毎日決まった時刻に高照 度光を浴びながら、生活プログラムに従事できる。

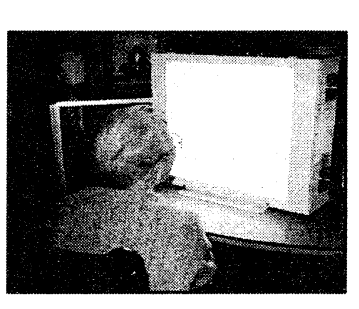

(a)

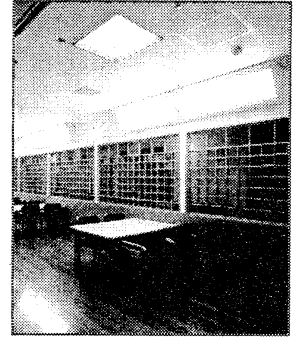

(b)
図 1 光照射装置 (a) および 高光束照明設備 (b) の例

\section{4. 光環境整備導入効果の事例}

\section{1 目的・実験方法}

老人保健施設に高光束照明設備を導入して高照度空間 を実現し、睡眠障害のある入所高齢者を対象に睡眠の質の 変化を評価する。

対象は、睡眠障害の訴えのある疾呆高齢者 6 例 $(86 \pm 5$ 歳)。いずれも睡眠薬の投与はなく、実験目的や計測内容 について本人または家族から文書による同意を得ている。 対象者が昼間の時間帯を過ごすデイルームの照明環境 を、計測開始から約 1 ケ月間は通常室内照明とし (Basel ine)、2 ケ月目は通常照明に加えて高光束照明設 備（図 1 (b) ; 松下電工製) を点灯した (Light)。点灯時間 帯は概小午前 10 時から午後 1 時の約 3 時間である。

睡眠覚醒りズムを長期間にわたり客観的・定量的に記録 するため、対象者のベッド上空に赤外線計測システム ${ }^{[6-7]}$ を設置し、 rest-activity（活動と休止のパターン）を2 ケ月に わたって無意識計測した。赤外線空間変化量の積算值 (体 動デ一夕) と、ベッド上の物体が寝具の高さ等から決まる 閾值を超えて存在している時間割合（在不在データ）を 1 分毎に記録した。 


\section{2 実験結果}

風邪などによる体調悪化の影響を除くため、介護記録に 「発熱」「（日常と異なる）投薬」が記載されている日の デー夕を除いた。次に Basel ine 期間、 Light 期間それぞ れ 1 ケ月間の夜間体動デ一夕を抽出し、施設の消灯時間に 一致する午後 9 時から翌朝 6 時の時間帯(以下夜間と記す) の\%体動ゼロ時間と体動総量（9 時間積分值）を算出した (図 2)。Basel ine 期間と Light 期間各 1 ケ月間平均值を 代表値としPaired-t 検定を行った結果、体動総量はLight 期間において有意な減少を示した $(p<0.05)$ 。体動ゼロ 時間についてはLight 期間で増加傾向が見られた。

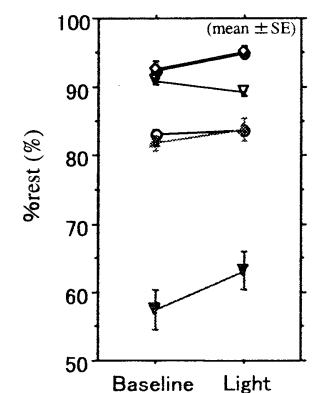

(a)

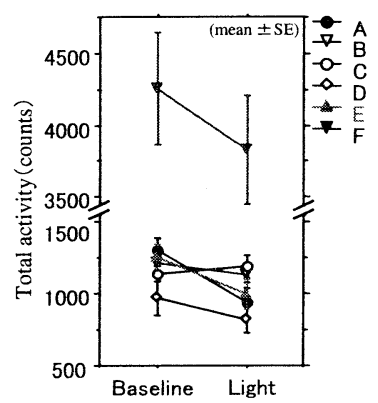

(b)
図2 夜間 rest-activity の比較 \%体動ゼロ時間(a), 体動総量(b).

\section{3 考察}

施設高齢者デー夕には介助による他動的体動が含まれ るため健常者との定量的な比較は困難であるが、自発・他 動のいずれの体動も、睡眠時には心拍数の増加や交感神経 系の交進をもたらす。その意味から頻繁な体動は睡眠の質 の低下 (睡眠の安定性や深い眠りが妨げられた状態)を示 唆するものである。図 2 に見られる Light 期間での\%体動 ゼロ時間の増加や体動総量の減少は夜間睡眠状態の好転 を示すものと言える。この結果は、睡眠脳波による先行研 究 ${ }^{[4]}$ と一致するものあり、施設において高齢者の昼間の受 光量を増やすことが入所者の睡眠覚醒りズムのメリハリ 向上につながると考えられる。

光環境整備を広めていく一つの条件は、現場スタッフが 光の生理的効果を理解し、活用ノウハウを蓄積することで ある。高照度空間を積極的に利用する生活プログラム作り などが本手法の有效性をさらに高める上で効果的と考え
られる。

\section{5. まとめ}

高齢者では、生体りズムの機能低下とともに同調因子が 不足し睡眠覚醒りズムが乱れがちである。施設高齢者の受 光量を自然な形で増すため、室内を高照度空間にする光環 境整備の取り組みが始まっている。

疾呆高齢者を対象とした実験の結果、光環境整備を実施 した期間に夜間睡眠状態の好転を示すデー夕が得られた。 今後介護スタッフとの連携などにより、さらに有効率の高 い照明環境の運用プログラムを提案していくことが課題 であろう。

\section{謝辞}

なお、本研究の一部は通商産業省・工業技術院 (現・経済産業 省）の産業技術基盤研究 研究開発プロジェクト「人間行動適合 型生活環境創出システム技術」として、新エネルギー・産業技術 総合開発機構 (NEDO) からの委託を受けて、社団法人人間生 活工学研究センター (HQL) を通して実施したものである。

\section{参考文献}

[1] 大川匡子: 老化と生体リズムをめぐる最近の進歩;老年精 神医学雑誌, VoL5, No.9, pp.1035-1042 (1994).

[2] Mishima, K., et al: Diminished melatonin secretion in the elderly caused by insufficient environmental illumination. ; J Clin Endocrinology \& Metabolism, Vol.81, No.1, pp.129-134 (2001).

[3] Koyama, E., et al: Bright light treatment for sleep-wake disturbances inaged individuals with dementia. ; Phychiatr Clin Neurosci, Vol.53, No.2, pp.227-229(1999).

[4] Fukuda, N., et al : Effects of bright light at lunchtime on sleep in patients in a geriatric hospital II ; Phychiatr Clin Neurosci, Vol.55, No.3, pp.291-293 (2001).

[5] Kim, S.., et al.: The effect of bright light on sleep and behavior in dementia: an analytic review. ; Geriatric Nursing, Vol.24, No.4, pp.239-243 (2003).

[6] Nakano, T., et al:: Application of an infrared sensor to home-monitoring of rest-activity patterns in a child with sleep disturbance. ; Sleep and Biological Rhythms, Vol.5, No.4, pp.483-489 (2003).

[7] 中野紀夫, ほか: 高齢者施設における睡眠の質の評価: 赤 外線センサの応用; ヒューマンインタフェース学会論文誌 Vol.5, No.4, pp.483-489 (2003). 
睡眠健康確保からの睬・心身のヘルスアップと地域普

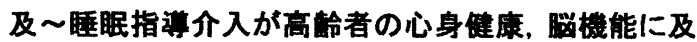
ほす効果

○田中 秀樹 (広島国際大学人閒塯境学部臨床心埋学科)

\section{【はじめに】}

これまで，睡居の問題む，䀢療領域でも治療・刘処としての 杵組みでタ取り扱子れることが多く, 生活課題行動医学; 予 防医学といらた視点て捉えられることは少なからた 高龄者の 心身の健康と密接に関係する睡眠問題の予防や対処 は，本人のみならず，かかわる家族や介護者の QOL を考える上でも社会的急務といえる.

本シンポジウムでは，高齢者の睡眠と健康につい て概説するとともに，健康生活の必須条件である快 適な睡眠確保に有効な生活指導法を科学的根拠，地 域保健現場での実践例を交えながら紹介する.

「睡眠と健康一ライフスタイルの見直しー」

近年, 睡眠は心と体の健康と密接に関係すること や，日本国民の 5 人に 1 人，特に高齢者の 3 人に 1 人が不眠で悩んでいることが報告 ${ }^{1)}$ され，高齢社会 化した我が国では，高齢者の不眠対策は大きな社会 問題となりつつある.WHO の国際共同研究によれば, 不眠患者の $50 \%$ が，1年以内に睡眠障害以外の医学的 治療にかかっていることが報告 ${ }^{2}$ されている。また， 近年の睡眠研究で明らかにされている睡眠の障害や 不足による脳・心身への影響 ${ }^{2-5)}$ も多岐にわたってお り，QOL を想像以上に阻害している. 一方，睡眠が 良好な人ほど日常生活動作能力（ADL）が高く, 主観 的健康感も高いことなど ${ }^{4)}$ もわかってきている。っ まり，寝たきりにならず，ボケない，元気で生き生 きとした健康生活を過ごすためには，適正な睡眠の 確保が重要になる。しかし，特に，高齢者において は，睡眠に問題がある場合でも，睡眠薬に対する反 応性の低下, 他疾患の治療薬との併用, 長期投与に よる常用量依存や副作用などの問題から，睡眠薬の 投与が困難な場合もある ${ }^{3)}$. 従って適正な睡眠の確 保のためには，ライフスタイルの改善が重要な意味 を持つ.

\section{「長寿県沖縄の高齢者に学ぶ」}

神縄と東京の高齢者のライフスタイルを比較し た研究 ${ }^{6)}$ では，沖縄の高齢者は睡眠健康が良好であ り,また, 睡眠健康の維持や増進には昼寝（特に午
後 1 3 時の間に 30 分間程度）や夕方の散歩，運動 （深部体温の最高期近傍）の非都市型の生活習慣が 重要な役割を果たしていることが指摘されており， 人間本来の体にあった古き良きライフスタイルを見 直す必要がある．さらに夜間睡眠の悪化は日中の適 正な覚醒維持機能の低下，とりわけ，夕方以降の居 眠りが有力な原因であることも指摘されている ${ }^{6-7)}$. 「昼寝は痴呆の予防にも效果的」

最近，健康な高齢者ほど短い昼寝を習慣的にとっ ていることや, 30 分以下の昼寝が不眠を予防するこ と $^{3,4,8)}$ がわかり，昼寝について見直しがせまられて いる. また, 30 分以下の昼寝は痴呆の発病の危険性 を 5 分の 1 以下に軽减させること，一方，1 時間以 上の昼漫は, アルツハイマー型痴呆の伦険性を 2 倍 に增加させることが指摘 ${ }^{9)}$ されている，つまり，習 慣的な短時間の昼寝は効果的だが，長すぎる昼寝は 逆効果になり，デイ・ホームや病院・施設等でよく 見受けられる長すぎる昼寝は，少し考え物であると いえる. 30 分以下の昼寝が，発病の危険性を低減す る要因としては，昼演で脳の疲労が軽城することや， 睡眠が改善することによって免疫機能が上昇する可 能性などが考えられている。

「睡眠健康教室一短い昼寝と夕方の軽運動」

不眠で悩む高齢者を対象に，昼食後の短時間昼寝 および夕方の軽運動（覚えやすく，座っても，寝て もできる軽いストレッチや腹式呼吸で習慣づきやす いもの；福寿体操）指導を 4 週間, 週 3 回介入的に 行うと, 覚醒の質が向上, 夕方から就床前にかけて の居眠りの減少がみられ，夜間の睡眠が改善するこ とが報告 ${ }^{4,7,8)}$ されている. また，日中の眠気の改 善や活動のメリ八リがでてくることや精神健康も改 善することも確認された. さらに，体力測定の結果 に柔軟性やバランス感覚, 脚筋力の測定值が有意に 向上し, 覚醒度, 意欲, 身体的瘦労, 集中力, 食欲 などの主観的評価も有意に改善していることが確認 されている ${ }^{7,8)}$ 。覚醒度や注意力, 柔軟性やバラン ス感覚, 脚筋力が改善したことは, 転倒, 骨折予防 に効果があり，寝たきり防止策にも有效であること を示している.

睡眠が改善したメカニズムのポイントは，日中の 適正な覚醒維持, 夕方から就床前にかけての居眠り 防止である，高齢者では，樑部体温の位相が若年者 


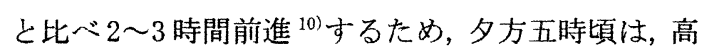
齢者にとって, 覚醒度, 樑部体温が高く, 運動には 望ましい時間帯 ${ }^{11)}$ となる.このため, この時間帯で の運動は覚醒系の活動を上昇させ, 夕方以降の居眠 りを堿らし, 就床前の覚醒の状態を質的に改善させ たと考えられる．短い昼寝により午後の覚醒維持が 容易になり，さらに夕方に軽運動をおこなうことで， 口中の喾醒の質が向上していたものと考えられる. また, 夜間睡眠が改善することにより, 翌日の覚醒 状態, 日中の眠気や活動量, 精神健康, コンピュー 夕認知課題の成績などが改善するることも指摘 ${ }^{3,8)}$ れており, 日巾の眠気低减が脳機能向上にも寄与し ているものと示唆される.つまり, 30 分の短い昼寝 と夕方の軽い連動が夜の質の良い睡眠を促し，また， 翌日起きている時も生活の質が高まるという良い循 環が形成されたといえる.

「睡眠健康活動のシステム化」

高齢者の日中の適正な覚醒の確保からの快眠法に 注目した, 新しいミニ, デイサービスプラン（快眠ミ ニ・デイサービス）が行われているこの取り組みで は, 前述の短い宣寝, 福寿体操の習慣づけに加え, グループワークを昼寝終了後と夕方の福寿体操の間 の時間帯に行なうことで, 夜間睡眠に影響しやすい 午後 3 時以降の覚醒維持を確実にした ${ }^{3,12)}$.この方 法は病院, 施設でのリハビリ等に応用可能といえる.

また，地域での睡眠健康指導の定着化には，簡便で 有効かつ継続性のある介入システムや評価法が必須 です ${ }^{12)}$.「ぐっすり・すっきり宣言」をスローガンに 揭げ，睡眠健康教室や睡眠の自己管理法の講習を展 開しているある町があり，そのシステムを一部紹介 する．まず，住民健診時に睡眠健康調查を行い，全 員に結果をフィードバックしている.ささら，睡眠 健康伦険度 ${ }^{87}$ の高い約 30 名に短期集中型の睡眠健康 教室「脳と心の癒し熟; 4 週閒, 週 3 回, 全 12 回」 を開催し，快眠とストレス緩和のための習慣づけを 行っている. 一方, 時間の都合等で, 教室に参加で きない不眠で悩む約 50 名に, 睡眠の自己管理法の講 䏨会を行い，教材や習慣行動チェックリストを用い て，1 ケ月，睡眠甘誌と目標行動票の記入法を指導 している. スリープマネージメントのポイントは,

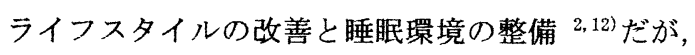
高齢の地域住民に対しては，ポイントをしぼり，睡
眠に有効な生活メニューを朝，昼（日中），夜に分 けて, 具体的な䏨慣行動を提案する方が実際に理解 が高く, 行動変容を促しやすいようである.

最後に; いまや不眠への予防・対策は, 脳や心の ヘルス・プロモーションに欠かせないものとしての 認識を地域全体で高める時代にきているといえる. 文献

1)Kim $\mathrm{K}$ et al. : An epidemiological study of insomnia among the Japanese general population, Sleep, 23 (1), 41-47, 2000.

2)Ustun $T$ et al:Mental Illness in General Health Care: an international study, London, John Wiley \& Sons, 1995.

3) 白川修一郎 - 他 : 睡眠 - 覚醒障害の生活習慣指導. 精神 科治療の理論と技法, 星和書店, 158-167, 1999.

4)田中秀樹 : 睡眠確保からの脳とこころのヘルスプロ モーション,地域保健 6:5-26, 2002

5) Drake et al: Effects of rapid versus slow accumulation of eight hours of sleep loss. Psychophysiology 38:979-987, 2001

6) 田中秀樹 - 他: 長寿県沖䋲と大都巾東京の高齢者の睡眠 健康と生活習慣についての地域間比較による検討。老 年精神医学雑誌, 11:425-433, 2000.

7)田中秀樹・他：不眠高齢者に対する短時間昼寝・軽運動 による生活指導介入の試み; 老年精神医学雑誌, 第 11 巻 10 号:139-1147, 2000

8)Tanaka $\mathrm{H}$ et al.: Sleep health, lifestyle and mental health in the Japanese elderly, Journal of Psychosomatic Research $56: 465-477,2004$.

9)Asada $T$ et al : Associations between retrospectively recalled napping behavior and later development of Alzheimer's disease: Association with APOE genotypes, Sleep, 23 (5): 629-634, 1, 2000.

10)Czeisler CA et al: Association of sleep-wake habits in older people with changes in output of circadian pacemaker. Lancet, 340: 933-936, 1992.

11)Atkinson et al: Circadian variation in sports performance. Sports Medicine, 21:292-312, 1996.

12) 田中秀樹: 高齡者に快眠をもたらを睡眠健康活動の提 案, 生活教育 48(1):39-48, 2004.

13）田中秀樹：快適睡眠と生活習慣病，痴呆予防，介護 ハンドブック,関西看護出版，90-135，2002

14)田中秀樹：脳と心身のへルス・プロモーションと しての睡眠指導介入と自己管理法, 診断と治 7 : $1219-1225,2004$ 